\title{
HER2/Neu Expression by Immunohistochemistry 0
}

National Cancer Institute

\section{Source}

National Cancer Institute. HER2/NeU Expression by Immunohistochemistry 0. NCI

Thesaurus. Code C147524.

An immunohistochemical result of 0 for HER2/Neu expression that is considered negative for expression. 